\title{
On the determinants of local government debt: Does one size fit all?*
}

\author{
Maria Teresa Balaguer-Coll \\ Universitat Jaume I
}

\author{
Diego Prior \\ Universitat Autònoma de Barcelona
}

\author{
Emili Tortosa-Ausina \\ Universitat Jaume I and Ivie
}

November 14, 2013

\begin{abstract}
This paper analyzes the factors that directly influence levels of debt in Spanish local governments. Specifically, the main objective is to find out the extent to which indebtedness is originated by controllable factors that public managers can influence, or whether it hinges on other variables beyond managers' control. The importance of this issue has intensified since the start of the crisis in 2007, due to the abrupt decline of revenues and, simultaneously, to the stagnation (or even increase) in the levels of costs facing these institutions face. Results can be explored from multiple perspectives, given that the set of explanatory factors is also multiple. However, the most interesting result relates to the varying effect of each covariate depending on each municipality's specific debt level, which suggests that economic policy recommendations should not be homogeneous across local governments.
\end{abstract}

Keywords: debt, local government, quantile regression

JEL Classification: D60, H71, H72, H74, H75

Communications to: Emili Tortosa-Ausina, Departament d'Economia, Universitat Jaume I, Campus del Riu Sec, 12071 Castelló de la Plana, Spain. Tel.: +34 964387168, fax: +34 964728591, e-mail: tortosa@uji.es

\footnotetext{
*All three authors are grateful for the financial support of Ministerio de Ciencia e Innovación (ECO201018967/ECON and ECO2011-27227/ECON). Maria Teresa Balaguer-Coll also acknowledges the financial support of Fundació Caixa Castelló-Bancaixa (P1.1B2012-07), and Emili Tortosa-Ausina is grateful for that of Generalitat Valenciana (PROMETEO/2009/066). The usual disclaimer applies.
} 


\section{Introduction}

Over recent years the problems of local treasury departments have increasingly become a focus of attention and concern in several euro area countries. Among the numerous problems affecting these departments, some of the most serious are related to high debt levels, which are now a focus of concern for local politicians, since it is frequently the case that the only way they can fulfill their commitments is through borrowing. It also presents a problem for public administration managers, as they are aware that higher levels of debt in their local administrations will lead to increased fiscal pressure. Politicians at a national level are also concerned, since indebtedness in numerous local councils will inevitably have an impact on the national economy.

In the particular case of Spain, on which we focus, local councils have become responsible for a growing number of powers (although still much lower compared to regions or comunidades autónomas), with a corresponding increase in the functions they perform, and resulting into higher expenditure levels. In addition, their basic resources are often insufficient to keep pace with the rate of growth of their expenditure needs (López-Hernández et al., 2012). ${ }^{1}$ These circumstances have led to high levels of indebtedness in most local government administrations. Although the problem of local debt is relatively modest on a national scale, due to the lower importance of the local public sector compared to the other public administrations (central and regional), ${ }^{2}$ it has become a threat to local government solvency and moreover, may have a negative effect on macroeconomic financial stability.

The severity of these issues has increased remarkably since the start of the financial crisis, which was followed by a real economic crisis, resulting in the burst of the housing bubble, a deep recession, and rising unemployment, which more than doubles the average rate in the European Union (EU). This new macroeconomic scenario has had a remarkable impact on the public sector, leading to very high levels of deficit across all strata of public administrations considered, i.e. central, regional or local-although the level of total debt is still lower than that of many other EU countries. In this new economic context, local governments have not been left unscathed, and for most of them the financial difficulties affecting them practically since the Spanish constitution was approved in 1978 have been exacerbated. The crisis has led to a sharp decline in municipal revenues while, simultaneously, their costs have either

\footnotetext{
${ }^{1}$ See also Zafra-Gómez et al. (2013) and González-Gómez et al. (2011) for related problems of Spanish municipalities.

${ }^{2}$ The Spanish regions or comunidades autónomas (autonomous communities) correspond to level NUTS3 of the European Union (Nomenclature of Territorial Units for Statistics), whereas municipalities correspond to level LAU2 (Local Administrative Units).
} 
stagnated or even increased, which impels local governments to find new tools for dealing with the new financial scenario (Brusca Alijalde et al., 2012). Therefore, it seems reasonable to design policies which take into account the major sources of debt for Spanish municipalities.

Several contributions have been analyzing the factors influencing past levels of local government debt, some examples of which include Inman and Fitts (1990), or Kiewiet and Szakaty (1996). These and related studies have dealt with the general issue of monitoring local government debt. Related to this literature, other relevant contributions have considered more specific questions such as the need to guarantee a balanced budget in the long run (Poterba, 1997), to preserve the principle of intergenerational equity when issuing debt (Musgrave, 1989), or to minimize the use of debt as a political instrument to prevent a disproportionate rise of taxes in constituencies (Cabasés et al., 2007).

The literature exploring explicitly the determinants of municipal debt, however, is not especially large, although some of the contributions are relevant. Cross-country studies are virtually nonexistent, which introduces certain difficulties when reviewing the international literature. Some previous relevant studies focusing on specific countries include, among others, Cropf and Wendel (1998), who examine the UK case, Ashworth et al. (2005) and Bastiaens et al. (2001), who analyze Flemish municipalities, or Baber and Gore (2008) and Bridges (2005), who focus on US local governments.

Taking this background into consideration, the objective of this paper is to analyze whether certain economic, political or social factors influence levels of debt in Spanish local government administrations. In this particular context, Guillamón et al. (2011) provide a recent summary of the literature focusing on different aspects of municipal debt. Our contribution to this growing literature is twofold. On the one hand, we attempt to reveal the extent to which the use of debt stems from factors that can be controlled, and over which managers can have an influence, or otherwise. In this general context, the existent literature finds some relevant variables explaining the level of municipal debt. On the other hand, we provide a different perspective on how to evaluate the impact of each explanatory variable on municipalities' debt.

Specifically, the available empirical literature, neither applied to the Spanish case or to different scenarios, has not considered the possibility that the effect of certain variables could depend on the level of debt of each particular local government, since all of them focused on the observable effects regarding the average level of debt. As a result, it might well be the case that a variable with a specific average impact could play a very different role depending on how indebted is the municipality under scrutiny. For instance, when relating the level of municipal 
debt to fiscal capacity, for local governments with few debts we can expect that the greater the fiscal capacity-i.e. the more revenues coming from the respective municipal resources-the lower the need to raise funds from external borrowing. On the opposite side, local governments having high fiscal capacity can make major investments because they may find easier to raise money by increasing their level of debt beyond the reasonable limits for municipalities presenting a poor fiscal capacity. Summing up, in contrast to the existent literature, we provide a different perspective in order to disentangle whether or not the variables explaining the level of municipal debt can be controlled by managers.

Our results can be helpful when designing strategic plans to reduce the level of debt because the first decisions to be made should concern to variables that have a significant impact and, in one way or another, are easily influenced by public managers. In particular, we found that for most of the variables, there existed a varying effect on debt, which largely contributed to explain some of the "mixed" findings in the literature; in other cases, the effect had even opposite signs for municipalities with differing levels of debt. Obviously, the combination of the two dimensions (degree of controllability and analysis for varying levels of debt) influences the level of severity of the problems caused by the existence of high levels of debt in municipalities.

The paper is structured in six sections. After this introduction, section 2 briefly outlines the theoretical framework regarding the determinants of local government debt, and their likely impacts, in order to discover whether managers can exert any influence on them. After presenting the empirical model in section 3, we provide information on the selected variables in section 4 . The results of the analysis are analyzed in section 5 and, finally, section 6 reports the main conclusions of the study.

\section{Theoretical framework: forces that influence local governments' public debt}

The literature on the determinants of municipalities' debt is heterogeneous in several respects. Given that differences can be quite remarkable, following Cropf and Wendel (1998) we have considered three general types of forces that can impact on municipal debt policies, namely, financial (or economic), political, and social forces. Some of them can be controlled by local governments, but others lie beyond their influence. However, due to the increasing importance of debt for growth in many cities around the world, and also due to the general increase in indebtedness (which clashes with the austerity policies being implemented in many European countries), it is important to understand which factors are having a stronger effect on municipal debt patterns, and their likely impact on city policies. 


\subsection{Fiscal/financial forces}

The first of these financial covariates can be broadly defined as "capital expenditure". We may term it INVEST, since these expenditures are included in those municipal budget categories corresponding to physical capital investments. Specifically, we will define it as total capital expenditures (capital transfers plus acquisitions of capital goods) divided by population. However, the variable is partially ambiguous, since there is no standard definition of what it exactly represents-even in the Spanish case. For instance, some authors such as Benito and Bastida $(2004,2005)$ define it as a ratio of real investments and capital transfers to total expenditures. However, other authors (Vallés et al., 2003; Cabasés et al., 2007) calculate it as the ratio of real investment to GDP, and refer to this variable as intergenerational equity-since future generations will also benefit from the capital investments that current generations may make. In contrast, Escudero (2002) defines it as the consolidated non-financial fixed assets per capita, whereas Fernández Llera et al. (2004) confine the contents of this variable to real investments only. In general-or, more exactly, on average-we can expect a positive relationship between debt and this variable. This occurs in the particular case we are dealing with, as Spanish law ${ }^{3}$ establishes that local governments can resort to long or short term public or private credit in any of its forms in order to finance their investment expenditure. The exact definition and descriptive statistics for this variable are provided in Tables 1 and 2, respectively.

The second of the selected variables is net savings, which we may refer to as NETSAV, and can broadly be described as the available funds municipalities can use to conduct their own investments. It corresponds to the difference between gross savings minus amortization expenses. Gross savings (which can be defined, following Fernández Llera et al. (2004), as the difference between current income minus current expenses) indicate local governments' capacity to cover financial amortization. Hence, the lower the level of gross savings, the higher will be the need to resort to borrowing. Previous contributions using this variable, although considering a slightly different definition, are Brusca and Labrador (1998), or Cabasés et al. (2007). The former authors consider a gross savings index in their use of the variables, whereas the latter define it as the ratio of net savings to GDP.

In this respect, Cabasés et al. (2007) also note how local governments that have an austere current expenditure policy, that obtain higher current income, or that plan debt amortizations appropriately, have a greater financing capacity, and are less likely to resort to borrowing to fund their investment expenses. Therefore, we may hypothesize a negative relationship

\footnotetext{
${ }^{3}$ LRHL, Ley Reguladora de Haciendas Locales, Law 39/1988 December $28^{\text {th }}$.
} 
between the levels of debt and net savings; in other words, when an institution has positive net savings, the need to resort to borrowing might be, cæteris paribus, lower.

Some previous contributions in the particular case of the debt levels of Spanish municipalities have considered a variable that corresponds to the ratio of non-financial surplus to deficit. We will refer to this variable as BUDGET which, in accounting terms (i.e. in terms of budget categories) can be broadly defined as the difference between the sum of the net recognized expenditures and the sum of net recognized revenues. However, this variable has been defined in different ways in the literature. For example, whereas Benito and Bastida $(2004,2005)$ calculate it in relative values, Brusca and Labrador (1998) consider total budgetary revenues and expenditure-in other words, the difference between total budgetary revenues and total budgetary expenditure, what they term budgetary deficit.

Although the specific definition of this variable might be subject to various interpretations, the sign of the impact on the levels of debt are not. If non-financial expenditures are higher than non-financial revenues, there will be a non-financial deficit and, therefore, it may be expected that the local government will have to go further into debt in order to balance such a deficit. Therefore, if we consider this variable as the ratio of non-financial budget expenditure to non-financial budget revenue, which we will refer to as BUDGET, its relation to debt should be positive, since local governments will turn to this resource more in order to balance the nonfinancial deficit.

The literature has also been considering a variable reflecting each municipality's own fiscal capacity, which is usually defined as the ratio of direct taxes, indirect taxes, and revenues from other taxes to all expenditures. It indicates the percentage of total revenues (excluding indebtedness) represented by municipalities' own resources, and some authors such as Vallés et al. (2003) refer to this variable as "fiscal responsibility"—although they define it slightly differently, dividing by GDP. These authors point out that the relationship between own fiscal capacity, which we may refer to as FISCCAP, and the level of debt is unclear since, in principle, municipalities that have more of their own resources will be under less pressure to borrow. However, the opposite effect may occur, as municipalities with more of their own resources will face lower financial risks and will therefore be granted certain advantages when accessing loans.

Finally, amongst the financial variables the literature has also included what we could refer to as "expenditure commitment" (EXPCOMM), which would correspond to the sum of personnel and financial expenditures divided by total expenditures. According to some 
authors such as Fernández Llera et al. (2004), the quantities in the numerator are usually very rigid (they are especially difficult to reduce), at least in the short run and, therefore, given such an inflexibility, municipalities might be impelled to issue debt. Therefore, the link we might expect between this variable and the levels of debt is positive.

\subsection{Socioeconomic forces}

The second set of variables we will consider can be broadly defined as socioeconomic variables. In this case, the number of available studies from which to choose the covariates is broader, as most of the variables included in this category have a more standard definition.

If our dependent variable were debt, without dividing it by population, one might consider as a key determinant the size of the municipality, measured by its population. In the literature the vast majority of authors consider that the effect of this variable on debt should be positive, since municipalities with a higher number of inhabitants are obliged to provide more services, as established by the Spanish law on local governments. Benito and Bastida (2004, 2005), Farnham (1985), or Fernández Llera et al. (2004), among many others, have put forward this argument.

However, Escudero (2002) considers that its effect is ambiguous and unclear, given that economies or diseconomies of scale in investments can alter the sign, depending on how the municipality's size is classified as established in the Law on Local Treasury Departments. In addition to this, considering size itself does not allow direct comparisons among municipalities of different sizes. Therefore, in both models considered we will be dividing by population and, consequently, it cannot enter the analysis as an explanatory factor.

Apart from population, some authors (Benito and Bastida, 2004, 2005) have included in the model the level of tourism (TOURISM). Tourist municipalities must face higher expenditure on infrastructures and a higher demand for services than other cities and, as a result, they will need to borrow more in order to meet this additional expenditure. The expected sign for this variable with regard to debt level should therefore be positive. The tourism variable has been used not only by Benito and Bastida (2005) and Benito and Bastida (2004), who introduced two dummy variables to differentiate between coastal and inland municipalities, but also by Escudero (2002), who used the tourism index from the "Anuario Económico de España" (Spanish Economic Yearbook) published by La Caixa Foundation. ${ }^{4}$

Previous studies have also considered per capita income. The link with the level of mu-

\footnotetext{
${ }^{4}$ See http:/ / www.anuarieco.lacaixa.comunicacions.com.
} 
nicipal debt is explained, among others, by Farnham (1985), who indicates that this variable would be reflecting the influence of a positive income elasticity of demand for capital goods, which would imply a positive link between this variable and debt. However, there is no total consensus on this point, and the expected sign for this variable is partly debatable; while some authors such as Clingermayer and Wood (1995) or Kiewiet and Szakaty (1996) consider its effect to be positive, others such as Adams (1977) claim a negative relationship.

This variable, also available through the Spanish Economic Yearbook, is estimated on the base of available household income figures by province provided in the INE $^{5}$ Regional Accounting section. In this particular Spanish case, previous studies considering this information include Benito and Bastida (2005), Benito and Bastida (2004), Cabasés et al. (2007), Escudero (2002), or Vallés et al. (2003), among others, who have used per capita income level as a possible indicator of economic level.

In our particular study we will not use economic level exactly since it is no longer available but rather the level of economic activity, which we will refer to as ACTIVITY. For year 2008 onwards, only the variable measuring economic activity is available. This is the one we use and, in addition, we consider that its link with a municipality's possible debt level is stronger than when considering per capita income, as those local governments operating in environments where the general economic activity is more intense will have to provide their constituencies with more and, probably, more complex services, which generally imply higher costs.

The literature has also been considering the density of the municipality (DENSITY), measured as inhabitants per square kilometer. Several recent contributions have considered the relation of this, or related variables, with municipality debt. For instance, according to HortasRico and Solé-Ollé (2010), the urban spatial structure of many Spanish cities, measured as urbanized land per person, not only has an environmental impact, but also a major impact on municipal finances. Benito et al. (2010) also consider similar issues. Specifically, they evaluate the impact of urban sprawl on municipal expenditures, finding that the higher the population density, the lower the total expenditures and current expenditures per capita which, in principle, would lead to lower levels of debt (negative relationship). This finding, in the opinion of Benito et al. (2010), would favor those voices asking for "smarter" growth in municipalities.

\footnotetext{
5“Instituto Nacional de Estadística” (Spanish Bureau of Statistics).
} 


\subsection{Political forces}

Numerous studies have associated aspects of a political nature (which we will refer to as political factors) with debt, such as political fragmentation, ideology (progressive or conservative) or the length of time in power. Although it is a highly nuanced question, the number of contributions in the field is remarkable, and these studies have been applied to very different contexts.

As indicated in Benito and Bastida (2004), political theory has traditionally claimed that left wing governments are more lax regarding governmental financial discipline. Therefore, this type of government would advocate a bigger public sector, generally with more powers, than right wing governments, which would ultimately become more indebted. Although a substantial number of studies have tested and corroborated this theory (see, for instance Blais and Nadeau, 1992; Dickson and Yu, 1997; Galli and Rossi, 2002), others have found the link was not significant (see, for instance, Abizadeh and Gray, 1993). In contrast some studies, albeit fewer in number, conclude that right-wing governments accumulate more debt when facing a higher probability of defeat; one example is Pettersson-Lidbom (2001), who examines debt accumulation among local governments in Sweden.

Other studies have also focused on related issues such as political fragmentation, or how long the governing parties remain in power. For example, Ashworth et al. (2005) analyze how greater political fragmentation leads to higher levels of debt and public deficit. However, in their study on a sample of 48 states in the USA, Clingermayer and Wood (1995) found that divided government did not lead to higher volumes of debt in the long term, and Bunch (1991) found that when the same party remains in power for various years (regardless of political ideology) they create public entities to provide loans in order to get round debt restrictions. Unfortunately, our database did not contain information on these variables and, therefore, their use had to be discarded. We will refer to this variable as POLITICAL, which is a dummy variable taking the value of 1 for municipalities governed by left-wing parties.

There are also some Spanish regions (Navarre and the Basque Country) which are classified under a special foral regime, which essentially gives them more independence in terms of managing transferred taxes and powers. In terms of municipalities, the minimum services that the local governments of these regions must supply is different from those that the rest of Spanish municipalities must provide. Therefore, one might hypothesize that these discrepancies turn into differences in terms of levels of municipalities' indebtedness. In our particular case, we will refer to this variable as FOR $A L$, and we will define it as a dummy variable taking 
the value of 1 for municipalities in the foral regions.

The expected sign for this variable could a priori be undefined. However, some authors such as Fernández Llera et al. (2004) consider that foral regions have created a relatively higher number of public firms (compared to the rest of Spain). Therefore, some municipalities might have decided to outsource some services which would lead to lower levels of municipal debt, pointing to a negative link with this variable. ${ }^{6}$

We can also consider the FORAL variable to be strongly linked to the issue of decentralization. Recent contributions have explored this issue in depth, such as, for instance, Lago-Peñas et al. (2011), or Pike et al. (2012). In the particular case of Spain, some authors such as BalaguerColl et al. $(2010,2013)$ have dealt with the specific issue of how the different levels of powers Spanish municipalities have might impact on the efficiency with which they provide their services. Specifically, Balaguer-Coll et al. (2013) argue that some municipalities with lower levels of powers might go beyond the legal minimum, providing more services than those legally required. This rationale would point to higher levels of debt. Therefore, one might hypothesize a negative link between the level of powers and the level of municipal debt. The variable POWERS takes the value of 1 for municipalities with fewer powers. Therefore, the sign one might expect is actually positive-because of how the variable is defined.

\section{Evaluating the determinants of local debt using regression quantiles}

In order to analyze how the variables reviewed in the previous section influence levels of debt, we will specify a model in which the dependent variable is the level of municipal debt per inhabitant. Consistent with the contents of the previous section, this model will consider the three groups of explanatory variables examined earlier (financial, socioeconomic and political), whose impact on debt operates through the mechanisms described above.

Since the dependent variable is the total municipal debt per inhabitant, many of the selected covariates will also be expressed as shares of population. Therefore, we might initially consider

\footnotetext{
${ }^{6}$ Other municipalities decide to cooperate to provide local public services (Bel et al., 2013).
} 
the following empirical model:

$$
\begin{aligned}
\left({\text { DEBT } / \text { POP })_{i}}_{i}\right. & =\beta_{0}+\beta_{1} \text { INVEST }_{i}+\beta_{2} \text { NETSAV }_{i}+\beta_{3} \text { BUDGET }_{i} \\
& +\beta_{4} \text { FISCCAP }_{i}+\beta_{5} \text { EXPCOMM }_{i} \\
& +\beta_{6} \text { TOURISM }_{i}+\beta_{7} \text { ACTIVITY }_{i}+\beta_{8} \text { DENSITY }_{i} \\
& +\beta_{9} \text { ELECTION }_{i}+\beta_{10} \text { FORAL }_{i}+\beta_{11} \text { POWERS }_{i}+\varepsilon_{i}
\end{aligned}
$$

Each of the lines constituting Equation (1) contains the three different types of variables considered in section 4 . The first line, afar the intercept $\beta_{0}$, contains the financial variables referred to in subsection 2.1 (INVEST, NETSAV, BUDGET, FISCCAP and EXPCOMM), the second line displays the socioeconomic variables described in subsection 2.2 (TOURISM, ACTIVITY and DENSITY), and the third one includes the political variables, described in subsection 2.3 (ELECTION, FORAL and POWERS). $\varepsilon_{i}$ is the error term corresponding to municipality $i$, with $i=1, \ldots, n$.

Models such as (1) are typically estimated using Ordinary Least Squares (OLS). Alternatively, we will consider quantile regression (Koenker, 2005), which allows estimation of the conditional quantiles of a response variable distribution (in our case, the debt of each municipality) in a linear model that provides a much more detailed and comprehensive view of likely causal relationships between our variables of interest. Specifically, the estimation of models such as those presented in the previous section are relevant, but they confine the analysis to providing information on average impacts, which in our case would be the average impact for the average municipality. Using this instrument, the analyst will only be able to determine whether the mean effect of a covariate on a response variable is significant or not.

Quantile regression is an alternative to conditional-mean modeling, in which conditional quantiles are modeled as functions or predictors. It is a natural extension of the linearregression model. The novelty is that, whereas the linear-regression framework specifies the change in the conditional mean of the dependent variable, the quantile regression model specifies changes in the conditional quantile. Therefore, it enables the problems referred to above to be tackled with more precision. Applications are growing in a variety of fields (see, for instance, the survey by Buchinsky, 1998), but they are still largely outnumbered by those using linear models which focus exclusively on average behavior. Therefore, quantile regression does not confine the analysis to regression against averages (and hence it is not limited in its explanatory values) but rather also uses information obtained from the underlying distribution of the dependent variable. 
In our case, quantile regression enables us to consider the entire distribution of local debt. Hence, we will be able to provide a more complete story of the relationship between variables-i.e. local debt and the relevant covariates. We can therefore specifically investigate whether, for municipalities whose debt is low (corresponding to the lower tail of the distribution, or to the lower quantiles), the sign and significance of the determinants is the same as for other municipalities whose debt is high (those lying in the higher tails of the distribution, and corresponding to the highest quantiles). This modelling will enable to design specific policies depending on each particular financial situation. Therefore, in the present study we consider that both low- and highly-indebted municipalities (especially the latter) are of interest in their own right-we do not want to consider them as outliers—and quantile regression allows us to analyze them in greater detail. ${ }^{7}$

Compared with basic models estimated via OLS, regression quantiles specify the $\tau^{\text {th }}$ quantile of the conditional distribution of $y_{i}$ given $x$ as a linear function of the covariates. As described by Koenker (2005), the estimation is carried out by minimizing the following equation:

$$
\operatorname{Min}_{\boldsymbol{\beta} \in \mathbb{R}^{k}} \sum_{i \in\left\{i: y_{i} \geq x^{\prime} \boldsymbol{\beta}\right\}} \tau\left|y_{i}-\boldsymbol{x}^{\prime} \boldsymbol{\beta}\right|+\sum_{i \in\left\{i: y_{i}<x^{\prime} \boldsymbol{\beta}\right\}}(1-\tau)\left|y_{i}-\boldsymbol{x}^{\prime} \boldsymbol{\beta}\right|
$$

where $y_{i}$ is the same dependent variable as in equation (1) for municipality $i, x$ is the vector of explanatory variables, $k$ is the number of explanatory variables, and $\tau$ represents the vector containing each quantile. The vector of coefficients $\beta$ to be estimated will differ depending on the particular quantile.

In the particular field of local government finances, these ideas have been barely explored, although there are some exceptions. For instance, Benito et al. (2010) find that the impact of population on municipal expenditures is not linear. Specifically, they find that population yields economies of scale up to a limit, since the functions present a U-shape, as from the point of the minimum per capita spending, if the population keeps on growing, per capita spending rises.

\section{Data description}

The sample comprises a large set of Spanish municipalities for which budgetary information is available for year 2008. ${ }^{8}$ It is important to note that, when selecting our budgetary information,

\footnotetext{
${ }^{7}$ In addition to this, the quantile regression estimator has other benefits such as being characteristically robust to outliers on the dependent variable.

${ }^{8}$ The Spanish Ministry of Economy and Finance website provides information on budgetary implementations up to and including 2008 (http://serviciosweb.meh.es/apps/EntidadesLocales/).
} 
we chose actual expenditure and revenues (net recognized assets and net recognized liabilities) rather than budgetary data (final expenditure and revenue forecasts), despite the fact that these budgetary implementations are not published promptly. If final forecasts had been used instead of actual implementations, results could have been severely distorted, since forecasts tend to underestimate expenditures and overestimate revenues.

Regarding the choice of year, we selected 2008 for a variety of reasons. First, it was the year in which the crisis actually started in Spain, although the effects for local governments were more evident the years after; therefore, its analysis provides a more unbiased view of local governments' finances. Second, in case we were interested in extending the analysis to more recent years, the information on debt is updated with some lag (up to four years). Finally, although extending the analysis to more years would grant the study with additional robustness, the number of regression quantiles figures, as well as the number of tables would increase the total length of the article to unreasonable limits. ${ }^{9}$

The choice of exogenous factors is guided by the theoretical framework presented in Section 2. Table 1 defines each one of the independent variables in the study, indicating also its expected impact on debt according to the theoretical framework, and if the variable is either controllable or non-controllable. Table 2 provides some summary statistics.

The different variables are provided by several sources. The fiscal variables are basically obtained from the municipalities' budgetary information-with the exception of population or GDP and population, which are provided by the Spanish Bureau of Statistics (INE). In the case of the socioeconomic forces, whereas TOURISM and ACTIVITY are provided by La Caixa Foundation (Spanish Economic Yearbook), DENSITY is provided by the INE. Regarding the political variables, the variables FORAL and POWERS have been constructed by the authors, whereas the POLITICAL variable is provided by the Spanish Ministry of the Interior (Ministerio del Interior).

\section{Results}

We report the results corresponding to the estimation of Model (2) in both Table 3 and Figures 1, 2 and 3. The results offer various subtleties compared to those one might obtain via OLS regressions. ${ }^{10}$ Amongst the financial covariates, those which were found to be significant throughout, and showed the expected signs were INVEST, NETSAV and BUDGET. However,

\footnotetext{
${ }^{9}$ However, these results are available from the authors upon request.

${ }^{10}$ These are available from the authors upon request, and were not reported for space reasons.
} 
as reported in Table 3, these are average effects which hide very disparate behaviors for the different parts of the conditional distribution of the dependent variable (DEBT/POP). For instance, the positive, and significant (average) effect found for INVEST is actually negative for the lowest tails of $D E B T / P O P$, i.e. for those municipalities with the lowest levels of debt. However, as shown by the standard errors in parentheses, the effect is not significant for quantiles $\tau=.05, \tau=.10$ and $\tau=.25$. In contrast, the effect is not only positive and significant for quantiles $\tau \geq .50$ but, in addition, the magnitude of the effect increases with the level of debt. In the case of NETSAV results are also much richer than the OLS results. In this case, the average negative, and significant, effect found is negative for all quantiles, as shown in Table 3, but the magnitude of the effect is much higher for the upper tail of the distribution of debt. In this case, however, the effect is also significant for all considered quantiles-with the sole exception of $\tau=.05$. The third financial variable which was found to be significant throughout via OLS, i.e. BUDGET, also shows remarkable differences for the quantile regression analysis. In this case, results are partly similar to those found for INVEST, although in this case the lowest quantiles do not show a negative effect. In this case, the effect is positive throughout, although significance holds only for the upper quantiles, and not for all of them. Analogously to what we found for INVEST and NETSAV, the magnitude is also much higher for the most indebted municipalities.

Those financial variables whose effect was not found to be significant on average, i.e. FISCCAP and EXPCOMM, share with the rest of the financial variables the increasing magnitude of the effect with the quantiles-i.e. the effect is always much stronger for the highest quantiles. For both FISCCAP and EXPCOMM the sign of the effect changes depending on the part of the distribution being analyzed-with a negative effect for the lower tail. In addition, some of the upper quantiles show a significant effect. Again, this behavior was completely overlooked by OLS regressions.

These results are corroborated in Figure 1, which displays the graphical counterpart to the results in Table 3 for the financial variables. As indicated in the figure, each sub-figure displays the slopes corresponding to the financial variables of the estimated linear quantile regression of Equation (2), which are plotted as functions of $\tau$, i.e. the different quantiles, which are represented on the horizontal axis, whereas the vertical axis represents the values of the slope coefficients for each quantile $(\tau)$.

Interestingly, the solid horizontal red line in each sub-figure represents the OLS estimates, and the dashed horizontal red lines represent 95\% confidence bands. Comparing them with 
the slopes of the estimated quantiles, it is easy to understand how misleading it can be to confine the analysis to OLS only. For instance, in the case of INVEST, we can observe that the variable is significant for $\tau>.5$ (approximately), since for values below this threshold the (gray) confidence bands contain the 0 . In the case of NETSAV, significance is only lost for the very upper and lower tails of the distribution, whereas for BUDGET we find that for $\tau<.3$ approximately the effect is not significant-at the $5 \%$ significance level. We can also notice how the effect varies with the quantiles. In the case of FISCCAP and EXPCOMM the confidence bands for OLS coefficients (dashed horizontal red lines) contain the zero, indicating that, on average, these variables are not significant, as stated earlier. However, the confidence bands for the estimated quantiles do not contain the zero for many of the quantiles (dashed black lines inside the gray bands), especially in the case of FISCCAP, indicating the effect of this variable is mostly positive.

In the case of the socioeconomic variables, one might a priori consider that the contribution of quantile regression would be minimal since, at least in the case of TOURISM and ACTIVITY, the effect is positive for OLS-as indicated by the solid red line in Figures 2a and $2 b$, respectively. However, paralleling the findings for the financial variables, the magnitude of the effect is much stronger for the most indebted municipalities, whereas the impact vanishes for the lower quantiles and, in addition, significance is partly lost-especially in the case of TOURISM, which is only significant for $\tau \geq .50$. In contrast, DENSITY is never significant and, in addition, the effect presents an erratic pattern throughout quantiles, which naturally leads to the conclusion that this variable is not significant at all.

Figures $2 \mathrm{a}, 2 \mathrm{~b}$ and $2 \mathrm{c}$ provide graphical counterparts for the coefficients estimated for the socioeconomic variables in Table 3. For both TOURISM and ACTIVITY the OLS results are corroborated, with effects of increasing magnitude which, in the case of TOURISM, are not significant for $\tau<.30$. In contrast the effect of DENSITY is both low (very close to zero), not significant, and without a clear sign.

Finally, the effect for the political variables also shows some nuances with respect to OLS. The variable ELECTION, which takes the value of 1 for those municipalities governed by left-wing governments, shows a positive effect throughout, corroborating what was found on average (solid red line in Figure 3a). This would imply that, on average, these municipalities have higher levels of debt. However, as shown in Table 3, the effect is not significant for the highest quantiles-i.e. the most indebted municipalities have these high levels of debt regardless of their political stance. Again, this result would be completely hidden by OLS. 
In the case of FORAL and POWERS, the nuances with respect to OLS are more marked. Whereas the variable FORAL shows no particular pattern for OLS (the effect was low, and not significant), for quantile regression (Table 3) the negative effect becomes positive, and non-negligible) for the highest quantiles $(\tau=.90, \tau=.95)$. However, in this case the effect is not significant. Yet significance actually exists for some quantiles, in this case the lowest ones ( $\tau=.05$ and $\tau=.25$ ). Taking into account that FORAL is a dummy variable taking the value of 1 for the foral regions (Navarre and the Basque Country), it would indicate that those municipalities with the lowest levels of debt are located in these regions. In the case of the municipalities with the highest levels, the effect is not significant.

Finally, the behavior of the decentralization variable (POWERS) is partly similar to that found for FORAL, since the sign of the effect varies with the conditional distribution of debt. In this case, however, there are more quantiles with a positive sign, and with significant effects. Since POWERS takes the value of 1 for the municipalities with fewer powers, a positive effect indicates that the municipalities with fewer powers have higher levels of debt. Results in Table 3 indicate this is actually the case for those municipalities with more debt, corresponding to the highest quantiles, and this effect is very strong. In contrast, for those municipalities with lower levels of debt, corresponding to the lowest quantiles, the effect is the opposite, and more modest in magnitude.

The effects of the three political variables considered are visually corroborated in Figure 3, which clearly shows clearly noticed how the effect of POLITICAL is present for most of the selected quantiles, whereas in the case of FORAL it only holds for few of them. In the case of POWERS, this effect is of the opposite sign (albeit significant) for both tails of the distribution of debt.

The results from the OLS and quantile estimation help us to detect the asymmetric situation of debts in Spanish local governments. On the one hand, municipalities having a low level of debts seem to be affected by the overall economic activity, but not by the tourism activity. The requirements concerning the level of investments do not appear to 'drive' increased level of debts. In other terms, the allocation of infrastructures seem to be financed without requiring funds from financial institutions, which helps these municipalities to avoid financial pressures. Cases with such characteristics can be taken as a 'best practice' model on how to manage the requirement of the external environment with an adequate structure of controllable budget variables (as the regressors concerning net savings indicate).

Confronting the previous case, local governments having a high level of debts appear to 
be influenced both by tourism and economic activities, and by operating with more powers in a decentralized environment, which can imply the requirement to offer a mixture of more sophisticated services to their citizens. For these municipalities, the investments increase the level of debts because control of the budgetary variables (i.e. the level of net savings) does not seem to reduce the requirement to raise financial debts. The obvious implication from this is that investments should be carefully monitored for municipalities offering complex services and maintaining important levels of economic activities once a certain level of debts is surpassed. In other words, to find an analogy from the private sector, a kind of 'debt covenant' should be introduced as a way to regulate the financial management of local governments. This regulation should only affect those municipalities having a level of debts beyond a determined point. The results of the quantile regression are extremely useful to determine the upper limit of the debts to regulate the level of municipal investments.

\section{Concluding remarks}

In Spanish public administration, all layers of government-central, regional and localcontribute to public spending, and have varying levels of powers. Although municipalities are clearly the level of government with the fewest less powers (the second decentralization, from the central and regional governments to local governments actually never took place), they are allowed to both raise local taxes and charge tariffs for the services they provide. These and other revenues they obtain from different sources allow them to, depending on the size of their populations, provide services such as day-care nurseries, public transport, waste disposal, sewage, construction, management of sports centers and public green areas, etc.

The current economic and financial crisis has seriously affected (and is affecting) European public administrations. In the Spanish case, all layers are heavily affected. However, there are many differences, since out of 17 regions ("comunidades autónomas") some of them are facing much higher deficits than others, especially those where the housing bubble was largest-and, therefore, when it burst the effects were more devastating. In those regions, the amount of revenues raised by regional governments has plummeted, whereas that of costs has either remained constant or even risen. Stepping down to the local government level, one finds a similar scenario, with the added problem that the number of municipalities is much higher (8,112 municipalities vs. 17 regions) and, therefore, the levels of heterogeneity are also much higher, with many municipalities facing extremely stringent financial needs, to which the responses have differed remarkably. 
Under these circumstances, this paper has analyzed the main determinants of local government debt in Spain. This question has been partly approached in previous contributions, which found relevant results. However, the previous literature implicitly assumed that the impact of the different variables was homogeneous across the 8,112 municipalities, disregarding the possibility that effects could vary for different quantiles of the distribution of municipal debt. In other words, most of the subtleties that might exist were hidden by the fact that results were summarized into an average effect. We consider that this might be an over-simplification, since based only on this summary, economic policy recommendations would not be tuned to match the intrinsic characteristics of each municipality.

Our results indicate that for most of the variables considered to have an impact on municipalities' debt, which were in line with those used by previous literature, the effects vary considerably depending on the quantile of the conditional distribution of local government debt. This implies that the explanations one might have previously found (explanations that did not take into account these differing effects by quantile) should state that the impacts found corresponded to average impacts. According to the analysis performed in this study, where we considered three types of variables, namely, financial, socioeconomic, and political, the effects are strong, and significant, for most of them. Interestingly, the effects differ greatly depending on how indebted municipalities are, and in some cases the impacts were even opposite for the lower and upper tails of the municipalities' debt distribution-such as, for instance, the variable reflecting devolution. In other cases, the effects were not significant for some parts of the distribution, but for others these effects were positive and significant, and this happened in a non-negligible, and relevant, number of instances. This is the case of, for instance, capital expenditures, non-financial surplus (as a share of deficit), own fiscal capacity, or tourism.

These results indicate that the design of public policies that attempt to control local governments' costs, strongly encouraged by European Union institutions, and contemplated by the recent update of the Stability and Growth Pact (2011), should take into account this varying reality, which is very present in the case of Spanish local governments. Failing to do so would lead to an design of public policies which, ultimately, could be ineffective in achieving the objectives pursued. 


\section{References}

Abizadeh, S. and Gray, J. A. (1993). Provincial government expenditures in Canada: An empirical analysis. International Review of Applied Economics, 7(1):69-90.

Adams, R. D. (1977). Individual preferences as supply determinants in the municipal and federal bond markets. Public Finance Quarterly, 5(2):175-202.

Ashworth, J., Geys, B., and Heyndels, B. (2005). Government weakness and local public debt development in Flemish municipalities. International Tax and Public Finance, 12(4):395-422.

Baber, W. R. and Gore, A. K. (2008). Consequences of GAAP disclosure regulation: Evidence from municipal debt issues. Accounting Review, 83(3):565-591.

Balaguer-Coll, M. T., Prior, D., and Tortosa-Ausina, E. (2010). Devolution dynamics of Spanish local government. Environment and Planning A, 42(6):1476-1495.

Balaguer-Coll, M. T., Prior, D., and Tortosa-Ausina, E. (2013). Output complexity, environmental conditions, and the efficiency of municipalities. Journal of Productivity Analysis, 39(3):303-324.

Bastiaens, E., De Borger, B., and Vanneste, J. (2001). Expenditure and taxation effects of local public debt and unconditional grants: evidence from flemish municipalities. Brussels Economic Review, 17(171):7189.

Bel, G., Fageda, X., and Mur, M. (2013). Why do municipalities cooperate to provide local public services? An empirical analysis. Local Government Studies, 39(3):435-454.

Benito, B., Bastida, F., and Guillamón, M. D. (2010). Urban sprawl and the cost of public services: an evaluation of Spanish local governments. Lex localis-Journal of Local Self-Government, 8(3):245-264.

Benito, B. and Bastida, F. J. (2004). The determinants of the municipal debt policy in Spain. Journal of Public Budgeting, Accounting and Financial Management, 16(4):525-558.

Benito, B. and Bastida, F. J. (2005). Análisis del endeudamiento en los Ayuntamientos: un Estudio Empírico. Revista Española de Financiación y Contabilidad, 126:613-635.

Blais, A. and Nadeau, R. (1992). The electoral budget cycle. Public Choice, 74(4):389-403.

Bridges, D. (2005). Public authorities and determinants of aggregate debt: Kentucky's municipal governments. Unpublished, pages 1-65.

Brusca, I. and Labrador, M. (1998). Análisis del endeudamiento en las Corporaciones Locales. Un estudio empírico. Revista de Hacienda Local, (84):581-597. 
Brusca Alijalde, I., Mora Agudo, L., and Montesinos Julve, V. (2012). La descentralización de servicios en el sector local: factores explicativos e implicaciones contables. Revista Española de Financiación y Contabilidad, 61(153):143-162.

Buchinsky, M. (1998). Recent advances in quantile regression models: a practical guideline for empirical research. Journal of Human Resources, 33(1):88-126.

Bunch, B. S. (1991). The effect of constitutional debt limits on state governments' use of public authorities. Public Choice, 68(1):57-69.

Cabasés, F., Pascual, P., and Vallés, J. (2007). The effectiveness of institutional borrowing restrictions: Empirical evidence from Spanish municipalities. Public Choice, 131(3):293-313.

Clingermayer, J. C. and Wood, B. D. (1995). Disentangling patterns of state debt financing. American Political Science Review, 89(1):108-120.

Cropf, R. A. and Wendel, G. D. (1998). The determinants of municipal debt policy: a pooled time-series analysis. Environment and Planning C, 16:211-224.

Dickson, V. A. and Yu, W. (1997). Spending by Canadian provincial governments: An empirical analysis. Public Finance/Finances publiques, 52(2):145-60.

Escudero, P. (2002). Endeudamiento, descentralización de los servicios y ciclos políticos presupuestarios: el caso de los ayuntamientos catalanes. PhD thesis, Universitat Autònoma de Barcelona, Barcelona.

Farnham, P. G. (1985). Re-examining local debt limits: A disaggregated analysis. Southern Economic Journal, 51(4):1186-1201.

Fernández Llera, R., García Valiñas, M. A., Cantarero Prieto, D., and Pascual Sáez, M. (2004). El endeudamiento de los gobiernos locales en España: Aspectos generales y resultados empíricos. In Caramés, L., editor, Situación actual de la hacienda local en España, pages 171-187. Asociación Galega de Estudios de Economía do Sector Público (AGEESP), Santiago de Compostela.

Galli, E. and Rossi, S. P. S. (2002). Political budget cycles: the case of the Western German Länder. Public Choice, 110(3):283-303.

González-Gómez, F., Picazo-Tadeo, A. J., and Guardiola, J. (2011). Why do local governments privatize the provision of water services? Empirical evidence from Spain. Public Administration, 89(2):471-492.

Guillamón, M. D., Benito, B., and Bastida, F. (2011). Evaluación de la deuda pública local en España. Revista Española de Financiación y Contabilidad, 150(150):251-285.

Hortas-Rico, M. and Solé-Ollé, A. (2010). Does urban sprawl increase the costs of providing local public services? Evidence from Spanish municipalities. Urban Studies, 47(7):1513. 
Inman, R. P. and Fitts, M. A. (1990). Political institutions and fiscal policy: Evidence from the US historical record. Journal of Law, Economics, and Organization, 6:79-132.

Kiewiet, D. R. and Szakaty, K. (1996). Constitutional limitations on borrowing: An analysis of state bonded indebtedness. Journal of Law, Economics, and Organization, 12(1):62-97.

Koenker, R. (2005). Quantile Regression. Cambridge University Press.

Lago-Peñas, I., Lago-Peñas, S., and Martínez-Vázquez, J. (2011). The political and economic consequences of decentralization. Environment and Planning C: Government and Policy, 29:197-203.

López-Hernández, A. M., Zafra-Gómez, J. L., and Ortiz-Rodríguez, D. (2012). Effects of the crisis in Spanish municipalities' financial condition: an empirical evidence (2005-2008). International Journal of Critical Accounting, 4(5):631-645.

Musgrave, R. A. (1989). Public Finance in Theory and Practice. McGraw-Hill, New York.

Pettersson-Lidbom, P. (2001). An empirical investigation of the strategic use of debt. Journal of Political Economy, 109(3):570-583.

Pike, A., Rodríguez-Pose, Tomaney, J., Torrisi, G., and Tselios, V. (2012). In search of the "economic dividend" of devolution: spatial disparities, spatial economic policy, and decentralisation in the UK. Environment and Planning C: Government and Policy, 30(1):10-28.

Poterba, J. M. (1997). Do budget rules work? In Auerbach, A., editor, Fiscal Policy: Lessons from Empirical Research, pages 53-86. MIT Press, Cambridge.

Vallés, J., Pascual, P., and Cabasés, F. (2003). Endeudamiento municipal y efectividad de las restricciones institucionales de disciplina crediticia. Hacienda Pública Española, 166(3):9-47.

Zafra-Gómez, J. L., Prior, D., Plata-DÍaz, A. M., and López-Hernández, A. M. (2013). Reducing costs in times of crisis: Delivery forms in small and medium sized local governments'waste management services. Public Administration, 91:51-68. 
Table 1: Definition of the relevant variables

\begin{tabular}{|c|c|c|c|c|c|}
\hline Type of variable & Variable name & Description & Definition/Calculation & Expected sign & $\begin{array}{l}\text { Controllable/non- } \\
\text { controllable } \\
\text { (short- } \\
\text { term } \\
\text { basis) }\end{array}$ \\
\hline \multicolumn{6}{|l|}{ Dependent variable } \\
\hline & $D E B T / P O P$ & Debt level per inhabitant & (Total debt)/population & & \\
\hline \multicolumn{6}{|c|}{ Independent variables } \\
\hline \multirow{5}{*}{ Financial/fiscal } & INVEST & Capital expenditures & $\begin{array}{l}\text { (capital transfers plus acquisitions of capital } \\
\text { goods)/population }\end{array}$ & $(+)$ & Controllable \\
\hline & NETSAV & $\begin{array}{l}\text { Net savings (available funds to conduct invest- } \\
\text { ments) }\end{array}$ & $\begin{array}{l}\text { (gross savings }- \\
\text { penses)/population }\end{array}$ & $(-)$ & $\begin{array}{l}\text { Controllable/non- } \\
\text { controllable }\end{array}$ \\
\hline & BUDGET & Non-financial deficit/non-financial surplus & $\begin{array}{l}\text { (non-financial budget expenditures, headings } \\
1 \text { to } 7 \text { of NRE)/(non-financial budget revenue, } \\
\text { headings } 1 \text { to } 7 \text { of NRR') }\end{array}$ & $(+)$ & Controllable \\
\hline & FISCCAP & $\begin{array}{l}\text { Own fiscal capacity (revenues represented by } \\
\text { municipalities' own resources) }\end{array}$ & $\begin{array}{llll}\text { (taxation revenues } & \left(\mathrm{NRR}^{\mathrm{b}} \text { headings } 1 \text { to }\right. \\
\text { 3))/(Total revenues) } & & & \\
\end{array}$ & $(+/-)$ & Controllable \\
\hline & ЕХРСОММ & Expenditure commitment & $\begin{array}{l}\text { (personnel and financial expenditures)/(total } \\
\text { expenditures) }\end{array}$ & $(+)$ & Controllable \\
\hline \multirow{3}{*}{ Socioeconomic } & TOURISM & Level of tourism & $\begin{array}{l}\text { Index based on the (local) tax on economic } \\
\text { activity (or Impuesto de Actividades Económicas, } \\
\text { IAE) with respect to tourism-oriented activi- } \\
\text { ties }\end{array}$ & $(+)$ & Non-controllable \\
\hline & ACTIVITY & Level of economic activity & $\begin{array}{l}\text { ((Local tax on economic activity (IAE) corre- } \\
\text { sponding to the municipality's economic ac- } \\
\text { tivities)/(total IAE } \text { IAvenues for all Spanish }_{\text {municipalities })) \times 100,000}\end{array}$ & $(+)$ & Non-controllable \\
\hline & DENSITY & Population density & Inhabitants per $\mathrm{km}^{2}$ & $(-)$ & Non-controllable \\
\hline \multirow{3}{*}{ Political } & POLITICAL & Color of municipality's governing party & $\begin{array}{l}\text { Dummy variable taking the value of } 1 \text { for mu- } \\
\text { nicipalities governed by left-wing parties, } 0 \\
\text { otherwise }\end{array}$ & $(+)$ & Non-controllable \\
\hline & FORAL & $\begin{array}{l}\text { Foral regions (Navarre and the Basque Coun- } \\
\text { try) }\end{array}$ & $\begin{array}{l}\text { Dummy variable taking the value of } 1 \text { for mu- } \\
\text { nicipalities in the foral regions }\end{array}$ & $(-)$ & Non-controllable \\
\hline & POWERS & Decentralization & $\begin{array}{l}\text { Dummy variable taking the value of } 1 \text { for mu- } \\
\text { nicipalities with less powers }\end{array}$ & $(+/-)$ & Non-controllable \\
\hline
\end{tabular}

a NRE: Net Recognized Expenditures.

b NRR: Net Recognized Revenues.

c IAS: Impuesto de Actividades Económicas (local tax on economic activity). 
Table 2: Descriptive statistics of the relevant variables

\begin{tabular}{|c|c|c|c|c|c|c|c|}
\hline Type of variable & Variable name & $\begin{array}{c}\# \text { of } \\
\text { observations }\end{array}$ & Mean & Std. Dev. & $1^{\text {st }}$ quartile & Median & $3^{\text {rd }}$ quartile \\
\hline \multicolumn{8}{|l|}{ Dependent variable } \\
\hline & $D E B T / P O P^{a}$ & 1,381 & 0.2851 & 0.2873 & 0.0686 & 0.2134 & 0.4151 \\
\hline \multicolumn{8}{|c|}{ Independent variables ${ }^{b}$} \\
\hline \multirow{5}{*}{ Financial/fiscal } & $I N V E S T^{\mathrm{a}}$ & 1,381 & 1.0355 & 0.1827 & 0.9336 & 1.0120 & 1.1090 \\
\hline & $N E T S A V^{\mathrm{a}}$ & 1,381 & 87.8060 & 422.6137 & -8.4856 & 51.7434 & 119.0209 \\
\hline & BUDGET & 1,381 & 1.0353 & 0.1827 & 0.9336 & 1.0118 & 1.1088 \\
\hline & FISCCAP & 1,381 & 0.4357 & 0.1528 & 0.3212 & 0.4407 & 0.5425 \\
\hline & EХРСОМM & 1,381 & 0.6517 & 0.1268 & 0.5770 & 0.6635 & 0.7438 \\
\hline \multirow{3}{*}{ Socioeconomic } & TOURISM" & 1,381 & 52.8704 & 349.2460 & 0.0000 & 2.0000 & 10.0000 \\
\hline & ACTIVITY $Y^{\mathrm{C}}$ & 1,381 & 56.4461 & 361.9620 & 2.0000 & 7.0000 & 23.0000 \\
\hline & DENSITY ${ }^{\mathrm{d}}$ & 1,381 & 0.0246 & 0.0355 & 0.0031 & 0.0119 & 0.0310 \\
\hline
\end{tabular}

${ }^{\mathrm{a}}$ In logs; DEBT in thousands of $€$.

${ }^{\mathrm{b}}$ All the political variables used are dichotomous variables and therefore their values are not reported.

"Both TOURISM and ACTIVITY are index numbers constructed by La Caixa Foundation. See "Anuario Económico de España" (Spanish Economic

Yearbook) for details (http:/ /www.anuarieco.lacaixa.comunicacions.com)

${ }^{\mathrm{d}}$ In square kilometers per inhabitant (i.e. inverse of the usual definition of density). 
Table 3: Regression quantiles, all variables

\begin{tabular}{|c|c|c|c|c|c|c|c|c|}
\hline \multirow{3}{*}{ Covariates } & & \multicolumn{7}{|c|}{ Dependent variable: $D E B T / P O P$} \\
\hline & & \multicolumn{7}{|c|}{ Quantile $(\tau)$} \\
\hline & & 0.05 & 0.10 & 0.25 & 0.50 & 0.75 & 0.90 & 0.95 \\
\hline & (Intercept) & $\begin{array}{l}0.146 \\
(0.046)\end{array}$ & $\begin{array}{l}0.220 \\
(0.066)\end{array}$ & $\begin{array}{l}0.123 \\
(0.079)\end{array}$ & $\begin{array}{c}-0.189 \\
(0.086)\end{array}$ & $\begin{array}{c}-1.012 \\
(0.165)\end{array}$ & $\begin{array}{c}-1.027 \\
(0.264)\end{array}$ & $\begin{array}{c}-1.243 \\
(0.430)\end{array}$ \\
\hline \multirow{5}{*}{$\begin{array}{l}\text { Fiscal/financial } \\
\text { variables }\end{array}$} & INVEST & $\begin{array}{c}-0.003 \\
(0.002)\end{array}$ & $\begin{array}{c}-0.006 \\
(0.005)\end{array}$ & $\begin{array}{c}-0.003 \\
(0.006)\end{array}$ & $\begin{array}{l}0.025 \\
(0.009)\end{array}$ & $\begin{array}{l}0.100 \\
(0.010)\end{array}$ & $\begin{array}{l}0.126 \\
(0.029)\end{array}$ & $\begin{array}{l}0.150 \\
(0.045)\end{array}$ \\
\hline & NETSAV & $\begin{array}{c}-0.104 \\
(0.103)\end{array}$ & $\begin{array}{c}-0.495 \\
(0.185)\end{array}$ & $\begin{array}{c}-1.016 \\
(0.244)\end{array}$ & $\begin{array}{c}-2.037 \\
(0.272)\end{array}$ & $\begin{array}{c}-1.981 \\
(0.508)\end{array}$ & $\begin{array}{c}-2.961 \\
(0.793)\end{array}$ & $\begin{array}{c}-3.159 \\
(1.163)\end{array}$ \\
\hline & BUDGET & $\begin{array}{l}0.000 \\
(0.006)\end{array}$ & $\begin{array}{l}0.013 \\
(0.023)\end{array}$ & $\begin{array}{l}0.036 \\
(0.035)\end{array}$ & $\begin{array}{l}0.118 \\
(0.045)\end{array}$ & $\begin{array}{l}0.195 \\
(0.065)\end{array}$ & $\begin{array}{l}0.205 \\
(0.109)\end{array}$ & $\begin{array}{l}0.256 \\
(0.183)\end{array}$ \\
\hline & FISCCAP & $\begin{array}{c}-0.009 \\
(0.007)\end{array}$ & $\begin{array}{c}-0.023 \\
(0.017)\end{array}$ & $\begin{array}{c}-0.001 \\
(0.028)\end{array}$ & $\begin{array}{l}0.158 \\
(0.042)\end{array}$ & $\begin{array}{l}0.126 \\
(0.074)\end{array}$ & $\begin{array}{l}0.157 \\
(0.098)\end{array}$ & $\begin{array}{l}0.137 \\
(0.170)\end{array}$ \\
\hline & ЕХРСОММ & $\begin{array}{c}-0.011 \\
(0.007)\end{array}$ & $\begin{array}{c}-0.025 \\
(0.033)\end{array}$ & $\begin{array}{c}-0.081 \\
(0.051)\end{array}$ & $\begin{array}{c}-0.116 \\
(0.060)\end{array}$ & $\begin{array}{l}0.215 \\
(0.111)\end{array}$ & $\begin{array}{l}0.164 \\
(0.180)\end{array}$ & $\begin{array}{l}0.229 \\
(0.290)\end{array}$ \\
\hline \multirow{3}{*}{$\begin{array}{l}\text { Socioeconomic } \\
\text { variables }\end{array}$} & TOURISM & $\begin{array}{l}0.001 \\
(0.001)\end{array}$ & $\begin{array}{l}0.004 \\
(0.003)\end{array}$ & $\begin{array}{l}0.003 \\
(0.004)\end{array}$ & $\begin{array}{l}0.023 \\
(0.006)\end{array}$ & $\begin{array}{l}0.032 \\
(0.009)\end{array}$ & $\begin{array}{l}0.059 \\
(0.013)\end{array}$ & $\begin{array}{l}0.069 \\
(0.026)\end{array}$ \\
\hline & ACTIVITY & $\begin{array}{l}0.003 \\
(0.002)\end{array}$ & $\begin{array}{l}0.012 \\
(0.005)\end{array}$ & $\begin{array}{l}0.041 \\
(0.007)\end{array}$ & $\begin{array}{l}0.049 \\
(0.009)\end{array}$ & $\begin{array}{l}0.103 \\
(0.016)\end{array}$ & $\begin{array}{l}0.088 \\
(0.022)\end{array}$ & $\begin{array}{l}0.097 \\
(0.036)\end{array}$ \\
\hline & DENSITY & $\begin{array}{l}0.000 \\
(0.007)\end{array}$ & $\begin{array}{c}-0.017 \\
(0.050)\end{array}$ & $\begin{array}{c}-0.046 \\
(0.116)\end{array}$ & $\begin{array}{c}-0.091 \\
(0.193)\end{array}$ & $\begin{array}{l}0.185 \\
(0.233)\end{array}$ & $\begin{array}{l}0.136 \\
(0.198)\end{array}$ & $\begin{array}{c}-0.142 \\
(0.867)\end{array}$ \\
\hline \multirow{3}{*}{ Political variables } & ELECTION & $\begin{array}{l}0.005 \\
(0.003)\end{array}$ & $\begin{array}{l}0.014 \\
(0.006)\end{array}$ & $\begin{array}{l}0.020 \\
(0.007)\end{array}$ & $\begin{array}{l}0.031 \\
(0.009)\end{array}$ & $\begin{array}{l}0.045 \\
(0.017)\end{array}$ & $\begin{array}{l}0.033 \\
(0.028)\end{array}$ & $\begin{array}{l}0.139 \\
(0.048)\end{array}$ \\
\hline & FORAL & $\begin{array}{c}-0.039 \\
(0.016)\end{array}$ & $\begin{array}{c}-0.032 \\
(0.036)\end{array}$ & $\begin{array}{c}-0.083 \\
(0.012)\end{array}$ & $\begin{array}{c}-0.006 \\
(0.076)\end{array}$ & $\begin{array}{c}-0.008 \\
(0.037)\end{array}$ & $\begin{array}{l}0.161 \\
(0.124)\end{array}$ & $\begin{array}{l}0.151 \\
(0.503)\end{array}$ \\
\hline & POWERS & $\begin{array}{c}-0.128 \\
(0.045)\end{array}$ & $\begin{array}{c}-0.183 \\
(0.048)\end{array}$ & $\begin{array}{c}-0.091 \\
(0.034)\end{array}$ & $\begin{array}{l}0.018 \\
(0.036)\end{array}$ & $\begin{array}{l}0.201 \\
(0.071)\end{array}$ & $\begin{array}{l}0.259 \\
(0.086)\end{array}$ & $\begin{array}{l}0.304 \\
(0.161)\end{array}$ \\
\hline
\end{tabular}


Figure 1: Regression quantiles, financial/fiscal variables

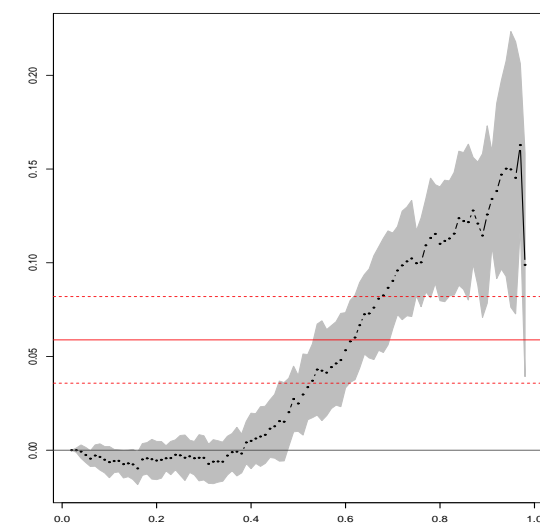

(a) INVEST

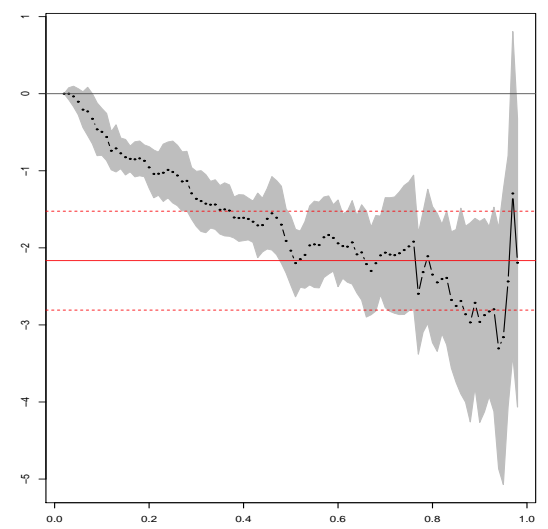

(b) NETSAV

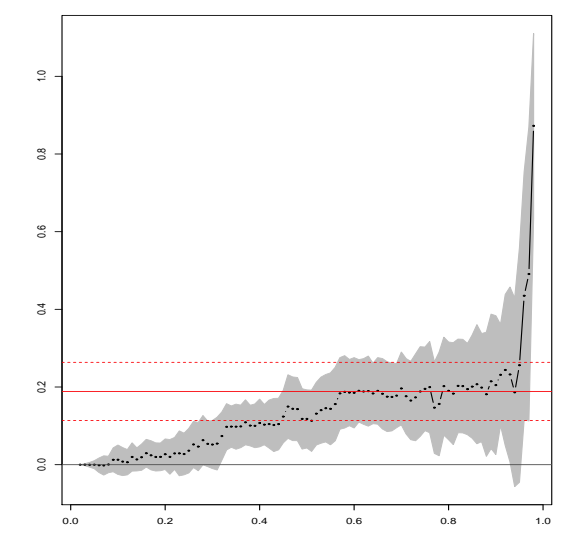

(c) BUDGET

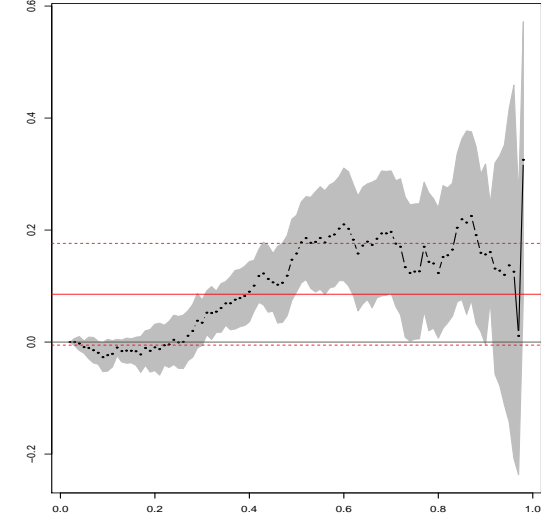

(d) FISCCAP

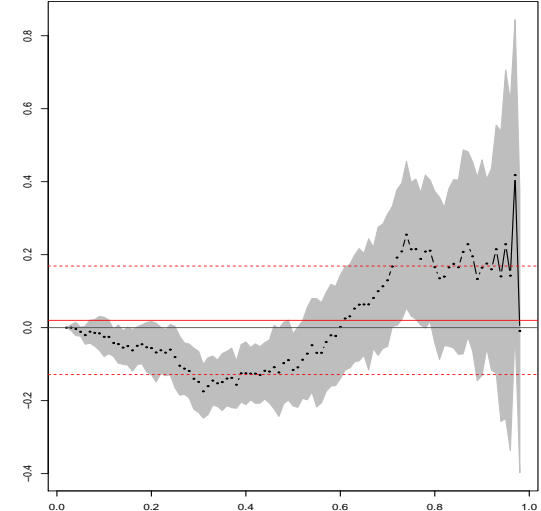

(e) $E X P C O M M$

Notes: the slopes corresponding to the financial/fiscal covariates of the estimated linear quantile regression for model (2) are plotted as a function of $\tau$ (i.e., the different quantiles), represented on the horizontal axis. The vertical axis represents the values of the slope coefficients for each quantile $(\tau)$. 
Figure 2: Regression quantiles, socioeconomic variables

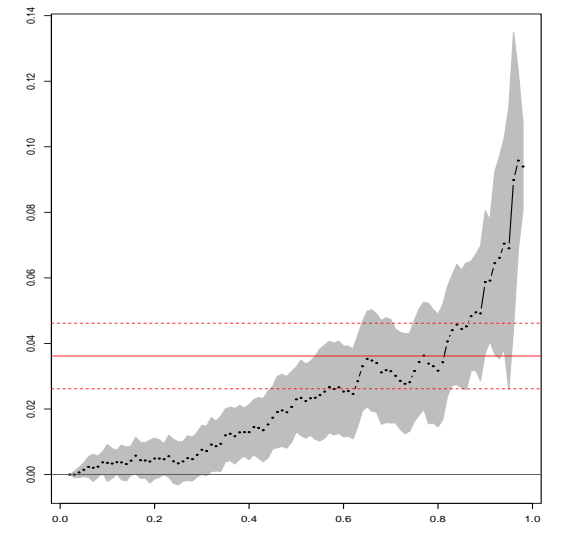

(a) TOURISM

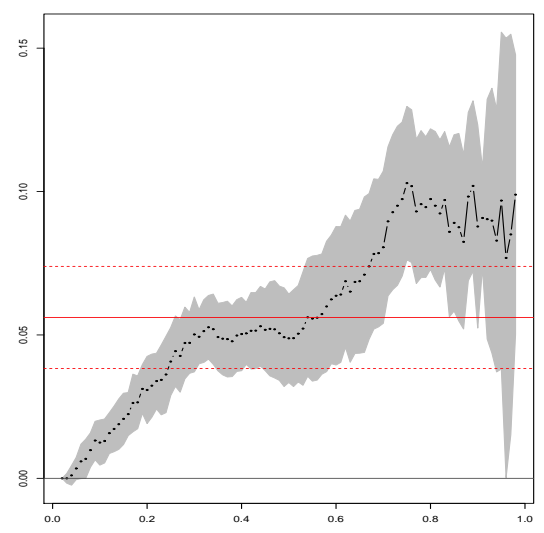

(b) ACTIVITY

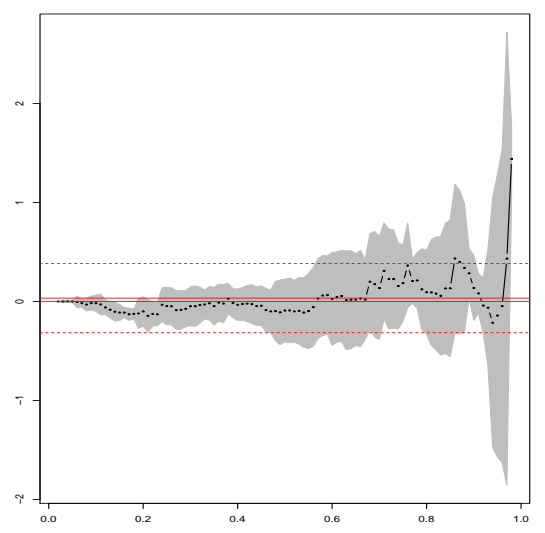

(c) DENSITY

Notes: the slopes corresponding to the financial/fiscal covariates of the estimated linear quantile regression for model (2) are plotted as a function of $\tau$ (i.e., the different quantiles), represented on the horizontal axis. The vertical axis represents the values of the slope coefficients for each quantile $(\tau)$. 
Figure 3: Regression quantiles, political variables

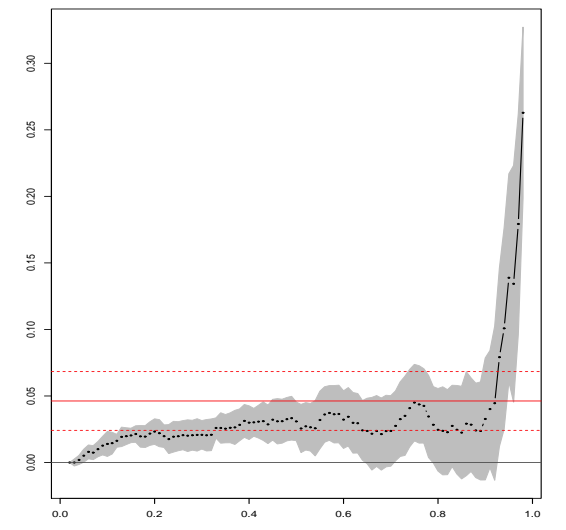

(a) ELECTION

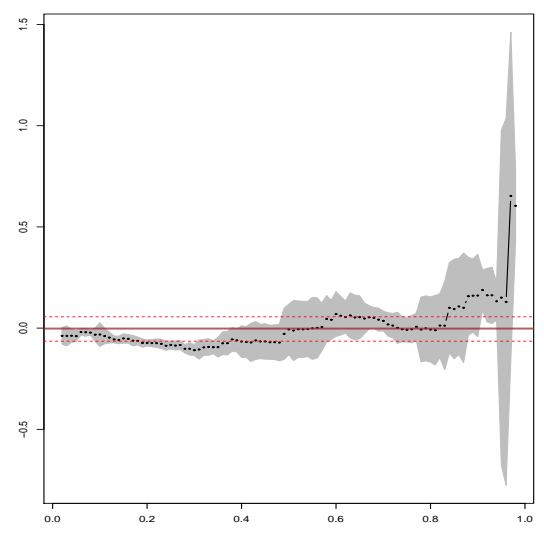

(b) FORAL

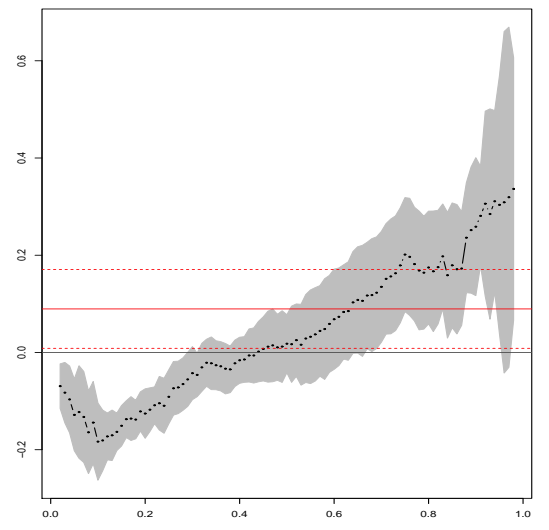

(c) POWERS

Notes: the slopes corresponding to the financial/fiscal covariates of the estimated linear quantile regression for model (2) are plotted as a function of $\tau$ (i.e., the different quantiles), represented on the horizontal axis. The vertical axis represents the values of the slope coefficients for each quantile $(\tau)$. 